Materiales de Construcción

Vol. 70, Issue 337, January-March 2020, e208

ISSN-L: 0465-2746

https://doi.org/10.3989/mc.2020.04019

\title{
Pozzolanic activity of argentine vitreous breccia containing mordenite
}

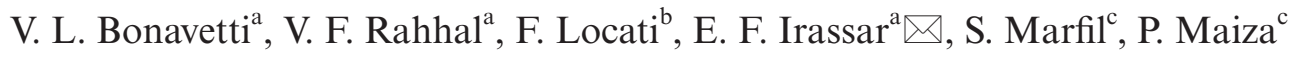 \\ a. Facultad de Ingeniería, CIFICEN (UNCPBA-CONICET-CICPBA), Olavarría (Buenos Aires, Argentina) \\ b. CICTERRA (CONICET-UNC), (Córdoba, Argentina) \\ c. Departamento de Geología, CGAMA (CIC-UNS), Bahía Blanca (Buenos Aires, Argentina) \\ $\triangle$ firassar@fio.unicen.edu.ar
}

Received 25 March 2019 Accepted 4 September 2019 Available on line 17 February 2020

\begin{abstract}
A vitreous breccia with variable amount of mordenite was studied for its use as pozzolan. The raw material was characterized by optical and scanning electron microscopy (SEM), X-ray diffraction (XRD), and the zeolite content was estimated by the methylene blue staining technique. After being ground, physical characteristics, cation exchange capacity (CEC), pozzolanicity, and the compressive strength activity index (SAI) were determined. The staining technique and the CEC measurement were used to evaluate the average content of zeolite. The vitreous breccia has pozzolanic activity after 7 days, the water demand increases slightly, and its addition stimulates the early hydration of portland cement. At later ages, the pozzolanic reaction around the grains, as revealed by SEM studies, improves the compressive strength of blended cements having a $\mathrm{SAI}>0.85$ at 28 days.
\end{abstract}

KEYWORDS: Pozzolan; Petrography; Blended cement; Hydration; Scanning Electron Microscopy (SEM)

Citation/Citar como: Bonavetti, V. L.; Rahhal, V. F.; Locati, F.; Irassar, E.F.; Marfil, S.; Maiza, P. (2020) Pozzolanic activity of argentine vitreous breccia containing mordenite. Mater. Construcc. 70 [337], e208 https://doi.org/10.3989/ mc.2020.04019

RESUMEN: Actividad puzolánica de una brecha vitrea argentina que contiene mordenita. Se estudió una brecha vítrea con cantidad variable de mordenita para su uso como puzolana. El material se caracterizó por microscopía óptica y electrónica de barrido (MEB), difracción de rayos X (DRX) y el contenido de zeolita se estimó mediante la técnica de tinción por azul de metileno. Luego de su molienda se determinaron las características físicas, la capacidad de intercambio catiónico (CIC), la puzolanicidad y el índice de actividad puzolánica a compresión (IAP). La técnica de tinción y la determinación de la CIC se utilizaron para evaluar el contenido promedio de zeolita. La brecha vítrea tiene actividad puzolánica después de 7 días, la demanda de agua aumenta ligeramente y su adición estimula la hidratación temprana del cemento portland. A edades tardías, la reacción puzolánica alrededor de los granos, observada mediante $\mathrm{MEB}$, mejora la resistencia a la compresión del cemento mezcla alcanzando un IAP $>0,85$ a los 28 días.

PALABRAS CLAVE: Puzolana; Petrografía; Cemento con Adiciones; Hidratación; Microscopía Electrónica de Barrido (MEB)

ORCID ID: V. L. Bonavetti (https://orcid.org/0000-0003-0910-8854); V. F. Rahhal (https://orcid.org/0000-0001-77101203); F. Locati (https://orcid.org/0000-0001-9067-1497); E. F. Irassar (https://orcid.org/0000-0003-4488-0014); S. Marfil (https://orcid.org/0000-0003-1903-7762); P Maiza (https://orcid.org/0000-0002-4738-3294)

Copyright: (C) 2020 CSIC. This is an open-access article distributed under the terms of the Creative Commons Attribution 4.0 International (CC BY 4.0) License. 


\section{INTRODUCTION}

The cement industry produces a large volume of $\mathrm{CO}_{2}$ emissions, which poses a challenge to commercial cement manufacture. According to the UNEP report (1), a viable way to reduce greenhouse gas emissions is to increase the amount of supplementary cementitious materials (SCMs) with low $\mathrm{CO}_{2}$ emissions and locally available as partial replacements in cementing materials with an equivalent or better performance. Natural pozzolans that only require a grinding process for their use as SCM are considered good candidates to achieve this goal $(2,3)$.

Pozzolans of volcanic origin have been used as hydraulic binder since ancient times, and thereafter, as SCMs in concrete worldwide (4). They are composed of vitreous or poorly crystalized materials that can form coherent or incoherent deposits (5) and can undergo diagenetic or low-grade metamorphic processes with subsequent zeolitization (6).

Zeolites are three-dimensional, microporous, crystalline solids with a well-defined structure. They are characterized by a framework of linked tetrahedral $(\mathrm{Si}, \mathrm{Al}) \mathrm{O}_{4}$ containing open cavities in the form of channels and cages occupied by water molecules and extra-framework cations that are commonly exchangeable (mainly $\mathrm{Ca}, \mathrm{Mg}, \mathrm{Ba}, \mathrm{Na}, \mathrm{K}$ and subordinate $\mathrm{Fe}, \mathrm{Sr}, \mathrm{Li}, \mathrm{Be}, \mathrm{Cs}, \mathrm{Cu}, \mathrm{Pb})(6,7)$. They exhibit high cation exchange capacity (CEC) that basically depends on the substitution degree of $\mathrm{Al}^{3+}$ by $\mathrm{Si}^{4+}$ in the structure. Due to their open porous structure, the water molecules come off easily when they are heated, giving a continuous dehydration curve. This process can be reversible (partially or totally), so the structural porosity and the channels can be refilled with water or a wide variety of other substances, conferring a high absorption-desorption capacity to these materials (8). This selective process mainly depends on the zeolite structure and the pore size and molecules, so they are used in different applications (9).

Volcanic zeolite-rich pozzolans are very heterogeneous, so the characteristics and properties of both the raw material (such as mineralogy, texture, chemistry, crystallinity, grain size, morphology, etc.) and the zeolite-bearing material (zeolite vs. glass proportion, particle size distribution, bulk chemistry, CEC, specific surface area, etc.) should be correctly assessed by different techniques. Knowing these heterogeneities is essential as they can affect the pozzolanic activity (10) and the water demand of the material, and ultimately, the properties of fresh and hardened concrete (11-18). In addition, they can accelerate the early hydration of portland cement (15) and contribute to the formation of additional hydrates $(12,19)$.

Natural zeolites (mainly zeolite-rich materials) are widely used in the cement industry, especially in China (20). Different studies have shown that when used as SCM in replacement of part of the cement, concrete durability can be improved ((21) and references therein). In Argentina, zeolites are recognized in different geological environments, mainly of a diagenetic or hydrothermal origin, but they are commercially available in the province of La Rioja only (22). Raggiotti et al. (23) studied a clinoptilolite-rich zeolitized tuff from the province of La Rioja as partial replacement of cement $(0 \%$ to $20 \%$ ). The material used is heterogeneous in size and their results indicate that it has good performance at $20 \%$ of replacement. In addition, Locati et al. (24) found that finely ground, this material can be used as inhibitor of the alkali-silica reaction (ASR).

In this paper, a zeolitized vitreous breccia (ZVB) from the province of Mendoza (Argentina) is characterized before and after being ground to evaluate its potential use as SCM. Its pozzolanic activity is investigated by several tests. Furthermore, the role of mordenite-type zeolite and the glass content in this breccia in pozzolan hydration is analyzed by $\mathrm{X}$-ray diffraction (XRD) and scanning electron microscopy-energy dispersive X-ray spectroscopy (SEM-EDS) techniques.

\section{MATERIALS AND METHODS}

\subsection{Raw zeolitized vitreous breccia (ZVB)}

The raw ZVB was extracted from an outcrop located in the south of the Mendoza province (Argentina). It is light green to whitish and has a small grain size. The mineralized sector is $\sim 200 \mathrm{~m}$ long and 6 to $10 \mathrm{~m}$ wide, with the base covered and the top exposed or partially covered by different materials.

Petrographic studies were done on thin sections under parallel and crossed nicols $(/ / \mathrm{N}, X \mathrm{~N})$ using an Olympus B2-UMA trinocular petrographic microscope. Morphological studies were performed with a LEO EVO 40-XVP SEM on gold-coated samples working at $10 \mathrm{kV}$. Additional studies were carried out on carbon-coated fractured surfaces and polished thin sections (abrasive size up to $1 \mu \mathrm{m}$ ) with a Carl Zeiss high resolution FE (Field Emission)Ligma SEM-EDS microscope, working at 8 and $15 \mathrm{kV}$ for images and microanalyses, respectively. Secondary electron (SE) images and backscattered electron (BSE) images were obtained. XRD analyses were performed on Rigaku D-Max III-C, with $\mathrm{Cu}-\mathrm{K}_{1,2}(\lambda=1.541840 \AA)$ radiation filtered with a graphite monochromator operating at $35 \mathrm{kV}$ and $15 \mathrm{~mA}$. Patterns were recorded on ground whole rock (in agate mortar), from 3 to $60^{\circ} 2 \theta\left(0.02^{\circ}\right.$ $2 \theta$ step and a counting time of 2 s per step).

Due to the irregular mineralization of the rock, the zeolite content was estimated by the following staining technique. One sample of the altered sector 
was cut and polished, obtaining a slab measuring $30 \times 25 \mathrm{~mm}$ and $10 \mathrm{~mm}$ in thickness. It was immersed in $0.01 \mathrm{~N}$ methylene blue solution for two minutes. After this treatment, photomicrographs were taken (30x magnification) under a stereomicroscope covering the total surface of the slab. Finally, the percentage of the stained area (zeolites are colored due to their CEC) was determined for each image with ImageJ software (25), and the average value was calculated for the whole slab.

\subsection{Characterization of the ground ZVB}

A representative ZVB sample was processed in a laboratory jaw crusher to obtain particles smaller than $4.75 \mathrm{~mm}$. Two kilograms of the crushed sample were dried at room temperature and ground in a laboratory ball mill until less than $12 \%$ was retained on $45 \mathrm{~mm}$ sieve. After grinding, the particle size distribution (PSD) and its parameters (d90, d50 and d10) were obtained by a laser diffraction granulometer (Malvern Mastersize 2000) with dry dispersant medium. The material retained on $45 \mu \mathrm{m}$ sieve by the wet method (26), the relative density (27) and the Blaine specific surface area (28) were also determined.

The chemical composition of the ground ZVB was determined by inductively coupled plasma emission spectrometry (ICP-ES) in ACME Laboratories, Canada (LF200 procedure). Additionally, it was characterized by simultaneous differential scanning calorimetry and thermogravimetric analysis (DSCTGA) and Fourier transform infrared spectroscopy (FT-IR). DSC-TGA was performed with a TA Q600 analyzer under inert atmosphere at a heating rate of $10{ }^{\circ} \mathrm{C} / \mathrm{min}$ from room temperature up to $1000{ }^{\circ} \mathrm{C}$. The FT-IR spectrum was recorded on a Nicolet 520 FT-IR spectrometer using $1 \mathrm{mg}$ pressed pellets of the raw material dispersed in $100 \mathrm{mg} \mathrm{KBr}$. For each spectrum, 100 scans were recorded in the $400-4000 \mathrm{~cm}^{-1}$ spectral range with a resolution of $4 \mathrm{~cm}^{-1}$ in transmittance mode.

The CEC and exchangeable cations (in solution) were determined in LANAQUI laboratory (Argentina). The sample was digested using nitric acid (29). Saturation with ammonium acetate was used to obtain the CEC. The chemical determinations were carried out with an Inductive Coupling Plasma Atomic Emission Spectrometer (ICP-AES), Shimadzu 9000 (30).

\subsection{Performance of the ZVB as SCM}

The ZVB-performance was assessed on blended cement containing an ordinary portland cement (OPC) with $25 \%$ by mass replacement as required by the IRAM 1654 standard for pozzolan (31). The chemical composition of OPC determined by $\mathrm{X}$-ray fluorescence (XRF) is given in Table 1, and
TABLE 1. Chemical composition of OPC.

\begin{tabular}{llllllllll}
\hline \multicolumn{8}{c}{ Chemical composition (weight \%) } \\
\hline $\mathrm{SiO}_{2}$ & $\mathrm{Al}_{2} \mathrm{O}_{3}$ & $\mathrm{Fe}_{2} \mathbf{O}_{3}$ & $\mathbf{M g O}$ & $\mathbf{C a O}$ & $\mathbf{S O}_{3}$ & $\mathbf{N a}_{2} \mathbf{O}$ & $\mathbf{K}_{2} \mathbf{O}$ & LOI* $^{*}$ \\
\hline 20.47 & 4.20 & 4.46 & 0.56 & 60.48 & 1.90 & 0.05 & 1.07 & 3.26
\end{tabular}

*LOI: loss on ignition

its mineralogical composition reported by the producer was $\mathrm{C}_{3} \mathrm{~S}=57.8 \%, \mathrm{C}_{2} \mathrm{~S}=13.7 \%, \mathrm{C}_{3} \mathrm{~A}=3.0 \%$, $\mathrm{C}_{4} \mathrm{AF}=14.2 \%$, gypsum $=5.0 \%$ and limestone $=$ $4.5 \%$. The strength class of OPC was 40 (standard compressive strength $>40 \mathrm{MPa}$ at 28 days).

The minislump test (32) was used to determine the flow and the flow loss on the cement paste. After standard paste mixing, the minicone placed on a glass plate was filled with the mixture and carefully lifted to allow the paste to flow on the glass. After $30 \mathrm{~s}$, two orthogonal spread diameters of the pad were measured and the average was calculated. The paste remaining in the bowl was remixed every 15 min to avoid bleeding, and the minislump was measured at 30, 60, and $120 \mathrm{~min}$.

The heat and cumulative heat release rate during cement hydration was measured in a conduction calorimeter operating under isothermal conditions at $20^{\circ} \mathrm{C}$ for $48 \mathrm{~h}$. The paste was prepared using $20 \mathrm{~g}$ of cementitious material in a small plastic bag carefully homogenized. The bag and mixing water were placed into the calorimeter until thermal stabilization, and then the cement was mixed with $10 \mathrm{~g}$ of water by hand for $30 \mathrm{~s}$, with a water-to-cementitious materials ratio $(\mathrm{w} / \mathrm{cm})$ of 0.50 by mass. The bag was sealed, carefully placed in the calorimetric cup, and the measurement was started immediately.

For the Frattini test (33), $15 \mathrm{~g}$ of OPC plus $5 \mathrm{~g}$ of ground ZVB were mixed with $100 \mathrm{ml}$ of boiled distilled water in plastic containers. Sealed containers were stored for $2,7,28$ and 90 days at $40^{\circ} \mathrm{C}$. At test time, samples were vacuum filtered through paper, and the filtrate was analyzed for $\left[\mathrm{OH}^{-}\right]$by titration against dilute $\mathrm{HCl}$ with methyl orange indicator and for $\left[\mathrm{Ca}^{2+}\right]$ by $\mathrm{pH}$ adjustment to 13 , followed by titration with $0.025 \mathrm{M}$ EDTA solution using murexide indicator. For this test, the mineral addition is considered active when the $[\mathrm{CaO}]$ and $\left[\mathrm{OH}^{-}\right]$determined in the supernatant solution are located below the solubility isotherm of $\mathrm{Ca}(\mathrm{OH})_{2}$ in alkaline solution at $40{ }^{\circ} \mathrm{C}$.

The strength activity index (SAI) was determined as the ratio between the compressive strength of the $\mathrm{OPC}+\mathrm{ZVB}$ and that of the OPC mortar curing at room temperature (34). The compressive strength was determined on prims $(40 \times 40 \times 160 \mathrm{~mm})$ made with standard EN 196-1 (35) mortar $(\mathrm{w} / \mathrm{cm}=0.5$ and cement:sand $=1: 3$ ). Prior to casting, the flow test was carried out according to ASTM C1437 (36). Specimens were cured for $24 \mathrm{~h}$ in the molds 
in fog room, and thereafter demolded and submerged in tap water at $20 \pm 1{ }^{\circ} \mathrm{C}$ until the test ages. At 2, 7, 28 and 90 days, the compressive strength was determined on three specimens (six values) using an INSTRON 33R4485 test machine. The mean value, the dispersion and the SAI were calculated. According to EN 450-1 standard (34), fly ash behaves as pozzolan when the SAI is higher than 0.75 at 28 days and higher than 0.85 at 90 days.

At 90 days, a slice of standard mortar specimen containing blended cement was studied by SEM (see LEO EVO equipment in section 3.1) operating at $20 \mathrm{kV}$. A carbon-coated polished thin section was prepared (abrasive size up to $1 \mu \mathrm{m}$ ) and studied by $\mathrm{BSE}$ images and mapping mode ( $\mathrm{Si}, \mathrm{Ca}, \mathrm{Al}, \mathrm{K}, \mathrm{Na}$, $\mathrm{Fe}, \mathrm{Mg}, \mathrm{S}$ ) to analyze the components of the cement paste, and line profile mode $(\mathrm{Si}, \mathrm{Al}, \mathrm{Ca}, \mathrm{Na}, \mathrm{K})$ to determine the chemical variation in the interfacial transition zone (ITZ).

The hydration compounds were determined on pastes made with w/cm of 0.5 and cured in sealed plastic bags at $20{ }^{\circ} \mathrm{C}$ for $2,7,28$ and 90 days. At test time, the paste was crushed, immersed in isopropyl alcohol to stop the hydration, and the nonevaporable water ( $\mathrm{Wn}$ ) was determined by using the procedure proposed by Powers (37). Other paste fragments were carefully ground in an agate mortar immersed in isopropyl alcohol and immediately measured by XRD analysis using the same equipment mentioned above.

\section{RESULTS}

\subsection{Raw ZVB characterization}

Petrographic studies show that ZVB is heterogeneous, with vitreous sectors slightly zeolitized in the upper part of the outcrop and other sectors strongly altered to zeolite, sometimes with good crystallinity (Figure 1a), which predominates in the lower sector of the outcrop. In the former, fluidal structures (with tubular microvesicles) and perlitic-spherulitic

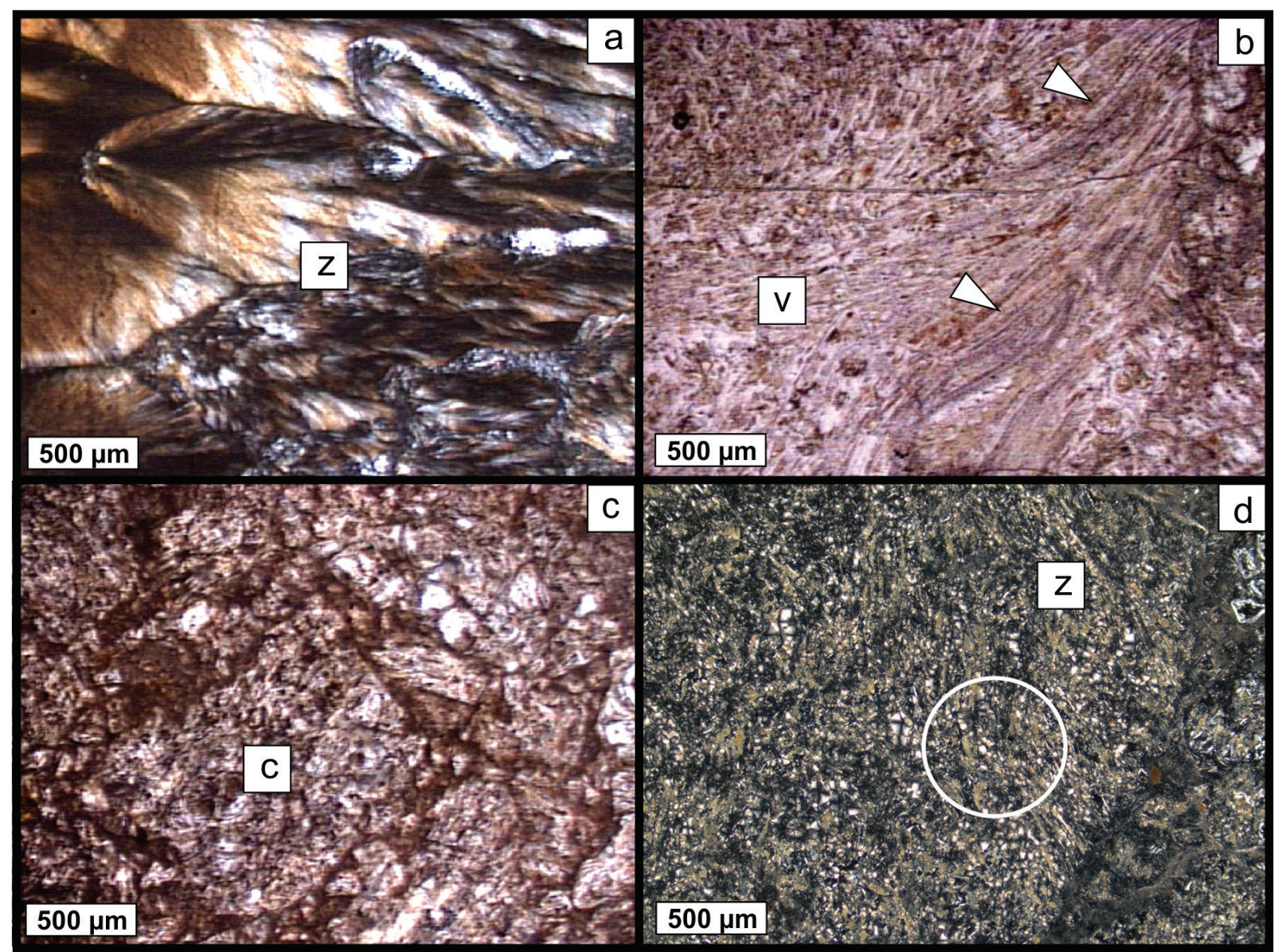

Figure 1. Photomicrographs of ZVB. a) Well-developed zeolite-rich zone $(X \mathrm{~N})$. b) Fluidal texture (arrows) in a volcanic glass-rich sector $(/ / \mathrm{N})$. c) General texture of ZVB with fragments of zeolitized and partially altered volcanic glass $(/ / \mathrm{N})$. d) Detail of a devitrified, altered sector in ZVB. Radial fibrous zeolites in a partially crystalline fine-grained mass can be observed (circle, $X \mathrm{~N}$ ). (z: zeolite-rich sector; v: volcanic glass-rich sector; c: clasts of ZVB). 
texture can be recognized (Figure 1b). Generally, more altered sectors are associated with zones of breccias of high permeability (Figure 1c). The heterogeneous reddish to brown coloration of some sectors is attributed to the presence of iron oxides/ hydroxides. A great percentage of the vitreous material shows anisotropy (partially crystalline), although mineral phases cannot be easily identified by this methodology. In these sectors, some fibrous zeolites $(\sim 50 \mu \mathrm{m}$ long) with radial growth are recognized, although zones with very fine grain size $(<10 \mu \mathrm{m})$ predominate (Figure 1d). As accessory phases $(<1 \%) \mathrm{K}$-feldspar, plagioclase, clay minerals and prismatic zeolite were identified.

SEM observation shows zeolite-rich sectors over volcanic glass. Also, well-developed fibrous zeolite (Figure 2a) is scarce and mainly associated with high permeability sectors (cracks and cavities), while zeolite of small grain size $(\leq 100 \mathrm{~nm})$ and with no obvious habit (Figure 2b) is the most distributed phase replacing the vitreous material. The texture is mottled (Figure 2c) with relicts of volcanic glass (light gray) in a fine-grained mass of mordenite (dark gray) (Figure 2d). In some sectors, veins of K-feldspar (white) are also observed crosscutting the rock texture. Table 2 lists the EDS analysis composition of the volcanic glass and the zeolite (spots 1 and 2 in Figure 2d, respectively).

XRD analysis (Figure 3 ) indicated that the main zeolite identified was mordenite (ICSD 00-029-1257) with main reflections at $9.06 \AA, 4.0 \AA$ and $3.48 \AA$. Additionally, plagioclase and $\mathrm{K}$-feldspar were identified as accessory phases. A hump of the background was observed between 20 and $30^{\circ} 2 \theta$, indicating the presence of amorphous material (relict volcanic glass). In some samples, opal-CT ( $\mathrm{SiO}_{2}$ phase) was also detected with minor amounts of clinoptilolite, beidellite-montmorillonite and Ti- or Fe-oxides, in agreement with other authors (38).

The zeolite content in the ZVB is variable, with $25 \%$ on average and a standard deviation of $6.6 \%$, although some sectors in the rock are almost totally

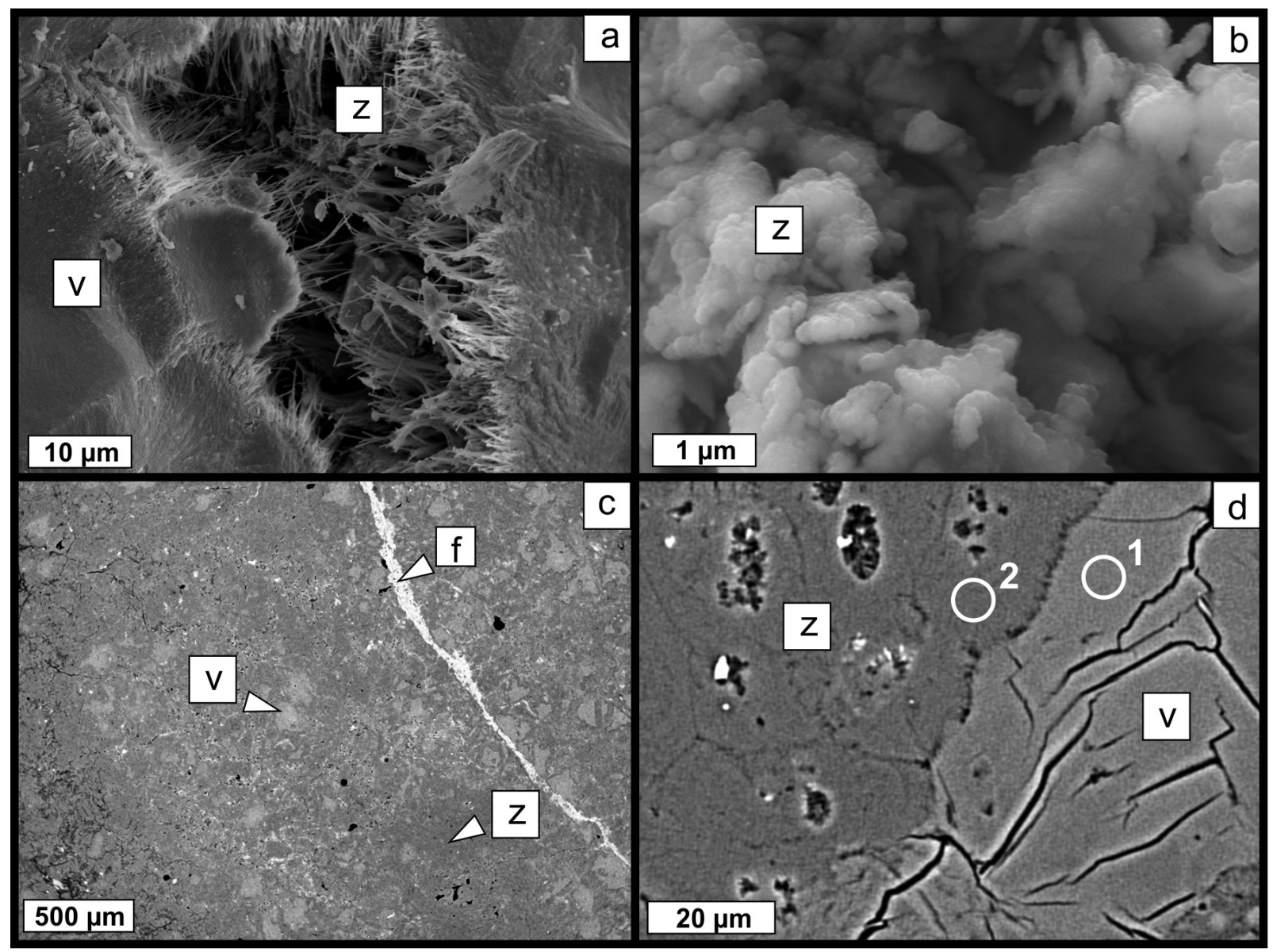

FIGURE 2. SEM of ZVB. a) Fibrous mordenite growing in a cavity over volcanic glass (SE - LEO EVO 40-XVP). b) Detail of vitreous sector being replaced by small and poorly formed zeolite crystals (SE - FE- Eigma). c) General texture of the mineralized zone (BSE - FE-Ligma). d) Detail of mordenite-volcanic glass interface (BSE - FE-Ligma). 1 and 2: Analyses listed in Table 2. (z: zeolite (mordenite); v: volcanic glass; $f$ : K-feldspar). 
TABLE 2. Chemical composition (\%) of volcanic glass (1: spot analysis in Figure 2d), mordenite (2: spot analysis in Figure 2d) obtained by FE- igma SEM-EDS, and bulk ground ZVB by ICP-ES. Mn, $\mathrm{Cl}, \mathrm{S}$ and $\mathrm{P}$ values are below the detection limit in the three analyses.

\begin{tabular}{lccc}
\hline & Volcanic glass (1) & Mordenite (2) & Ground ZVB \\
\hline $\mathrm{SiO}_{2}$ & 69.48 & 71.26 & 69.27 \\
$\mathrm{Al}_{2} \mathrm{O}_{3}$ & 12.25 & 10.60 & 10.93 \\
$\mathrm{Fe}_{2} \mathrm{O}_{3}$ & $b d l$ & $b d l$ & 0.74 \\
$\mathrm{MgO}$ & 0.64 & 0.00 & 0.27 \\
$\mathrm{CaO}$ & 3.02 & 2.85 & 2.61 \\
$\mathrm{Na}{ }_{2} \mathrm{O}$ & 0.46 & 1.77 & 1.43 \\
$\mathrm{~K}_{2} \mathrm{O}$ & 2.67 & 1.73 & 2.18 \\
$\mathrm{BaO}$ & 0.70 & 0.00 & $b d l$ \\
$\mathrm{TiO}_{2}$ & $b d l$ & $b d l$ & 0.09 \\
$\mathrm{LOI}^{*}$ & - & - & 12.30 \\
$\mathrm{H}_{2} \mathrm{O}^{* *}$ & 10.78 & 11.79 & - \\
\hline
\end{tabular}

bdl: Values below the detection limit of the equipment. *LOI: loss on ignition

$* * \mathrm{H}_{2} \mathrm{O}$ : calculated as the difference to reach $100 \%$.



FIGURE 3. XRD pattern of ZVB (M: mordenite, F: K-feldspar, P: plagioclase).

zeolitized ( $80 \%)$. More permeable sectors such as cavities and cracks show intense blue staining, while the rest of the matrix is blue to light blue (Figure 4). The non-zeolitized vitreous clasts are not stained. The content of vitreous phase determined by this method assuming a small influence of other crystalline phases (K-feldspars, plagioclase, Opal-CT and oxides) ranges between $70 \%$ and $75 \%$.

\subsection{Ground ZVB characterization}

The physical characteristics of the ground ZVB are summarized in Table 3 and compared to those of OPC. The PSD curves for ZVB and OPC are presented in Figure 5, and their granulometric parameters are reported in Table 3. A grinding time of 120 min was necessary so that less than $12 \% \mathrm{ZVB}$ was retained on $45 \mu \mathrm{m}$ sieve. The PSD curve of ZVB has unimodal distribution with a high volume of particle size at $21.4 \mu \mathrm{m}$ and two humps at $5.4 \mu \mathrm{m}$ and $0.9 \mu \mathrm{m}$. Compared with OPC, the PSD is thinner. The specific surface of ZVB determined by the Blaine method was larger than that of the OPC, and the density value was lower.

Table 2 also reports the chemical composition of the ground ZVB. The sum of $\mathrm{SiO}_{2}+\mathrm{Al}_{2} \mathrm{O}_{3}+\mathrm{Fe}_{2} \mathrm{O}_{3}$ $(80.1 \%)$ is greater than $70 \%$ and the $\mathrm{SO}_{3}$ is below the detection limit of the equipment, allowing the chemical requirements of ASTM C618 (39) for natural pozzolan Class N. However, the structural water content in this type of pozzolan causes a LOI greater than $10 \%$ as required by the standard.

The TGA curve (Figure 6 - solid line) of the ground ZVB shows a continuous mass loss during heating, attaining a total mass loss of $11.93 \%$. Between 20 and $110{ }^{\circ} \mathrm{C}$, the mass loss is assigned to desorption of free water into the zeolite structure (hygroscopic water), while the mass loss in the $110-230^{\circ} \mathrm{C}$ range is attributed to desorption of very loosely held water $(40,41)$. A broad endothermic peak is recognized in the DSC curve (heat flow) in the $20-230^{\circ} \mathrm{C}$ range due to these two processes (42). The mass loss above $230^{\circ} \mathrm{C}$ could be due to strongly bound water (43) or the dehydroxylation of zeolite (44). According to Pechar and Rykl (43), mordenite is stable up to $510^{\circ} \mathrm{C}$ without significant changes in its structure.

Figure 7 shows the FT-IR spectrum of the ground ZVB. The main bands were assigned according to Jansen et al. (45), Deshpande \& Bhoskar (46) and Ostroumov \& Corona-Chávez (47). The 3620 and $3454 \mathrm{~cm}^{-1}$ bands are well defined and are assigned to the $\mathrm{OH}$-stretching vibration, while the $1643 \mathrm{~cm}^{-1}$ band is due to $\mathrm{H}-\mathrm{O}-\mathrm{H}$ bending of water. The vibration of $\mathrm{T}-\mathrm{O}$ bending is assigned to 1223 and $791 \mathrm{~cm}^{-1}$ (external asymmetric and symmetric stretching, respectively), 1051 and $727 \mathrm{~cm}^{-1}$ (internal asymmetric and symmetric stretching, respectively), and $469 \mathrm{~cm}^{-1}$ bands (possibly bending). The bands at 627,577 and $523 \mathrm{~cm}^{-1}$ could be attributed to double-ring tetrahedral vibrations. Minor peaks observed at 2879,2232 and $1440 \mathrm{~cm}^{-1}$ could not be assigned.

Table 4 gives the results of CEC and exchangeable cations of the ground ZVB (average of two determinations). According to Mumpton (48), the CEC of mordenite is $2.29 \mathrm{meq} / \mathrm{g}$ (calculated from unit-cell formula). Therefore, considering the CEC determined, $\sim 25.8 \%$ of mordenite in ZVB can be estimated, which is similar to the percentage determined by the staining technique. 


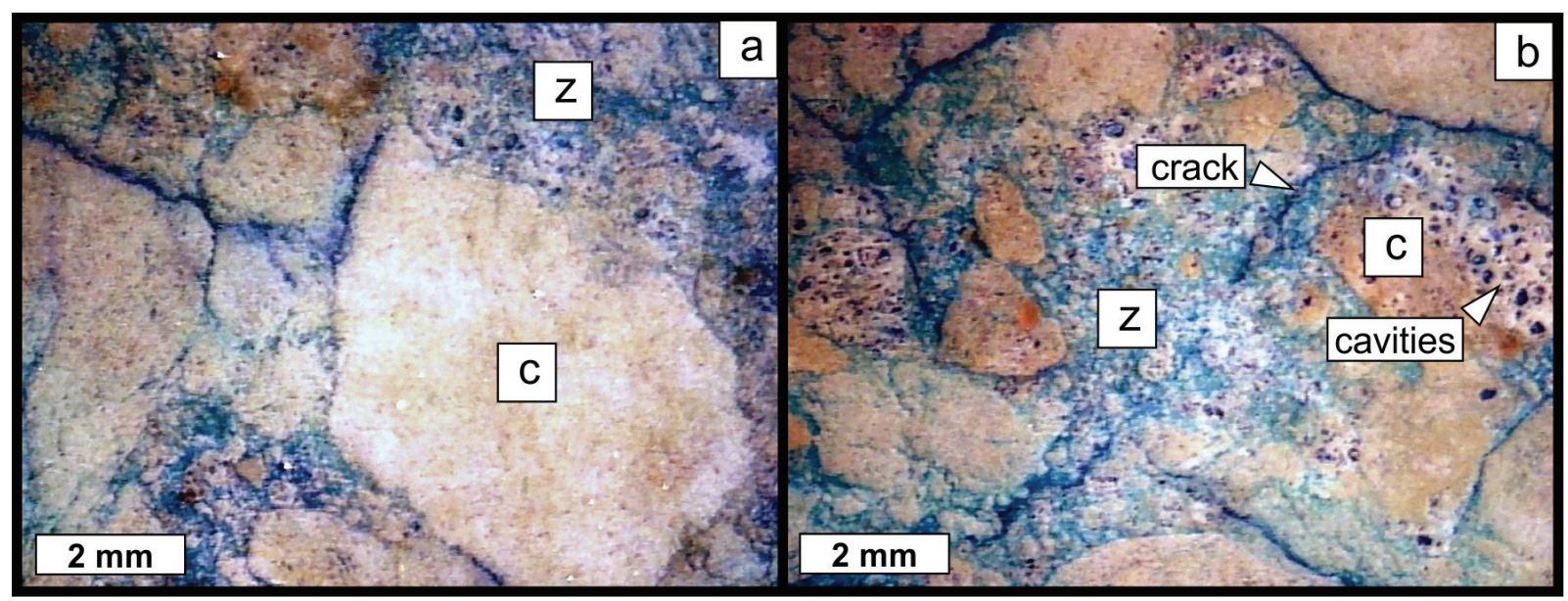

FIGURE 4. Photomicrographs of stained polished slab. a) Sector with predominance of non-zeolitized vitreous clasts. b) Sector with predominance of strongly zeolitized matrix. (c: vitreous clasts. z: highly zeolitized matrix).

TABLE 3. Physical properties of the ground ZVB and OPC.

\begin{tabular}{lcccccc}
\hline & \multirow{2}{*}{$\begin{array}{c}\text { Density } \\
\text { Material }\end{array}$} & $\begin{array}{c}\text { Specific } \\
\left(\mathbf{g} / \mathbf{c m}^{\mathbf{3}}\right)\end{array}$ & $\begin{array}{c}\text { Retained on } \\
\text { surface }\left(\mathbf{m}^{\mathbf{2}} / \mathbf{k g}\right)\end{array}$ & $\mathbf{4 5} \boldsymbol{\mu m}$ sieve $(\mathbf{\%})$ & \multicolumn{3}{c}{ PSD parameters $(\boldsymbol{\mu m})$} \\
\cline { 5 - 7 } Ground ZVB & 2.14 & 798 & 4.80 & 33.53 & 2.61 & 1.23 \\
OPC & 3.13 & 354 & 2.85 & 60.74 & 18.72 & 2.74 \\
\hline
\end{tabular}

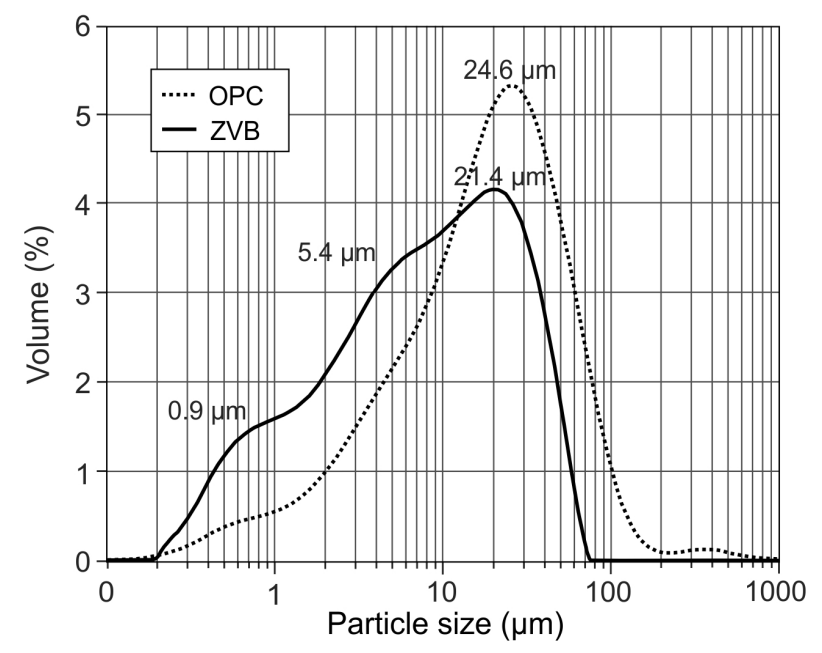

FIGURE 5. PSD curves of the ground ZVB and OPC.

\subsection{Performance of ground ZVB as SCM}

\subsubsection{Minislump test}

Figure 8 shows the flow spread diameter $(\mathrm{cm})$ as a function of time (min) for OPC and OPC + ZVB pastes. For OPC paste, the initial spread diameter $(10.2 \mathrm{~cm})$ was higher than that corresponding to $\mathrm{OPC}+\mathrm{ZVB}(7.8 \mathrm{~cm})$, confirming water consumption

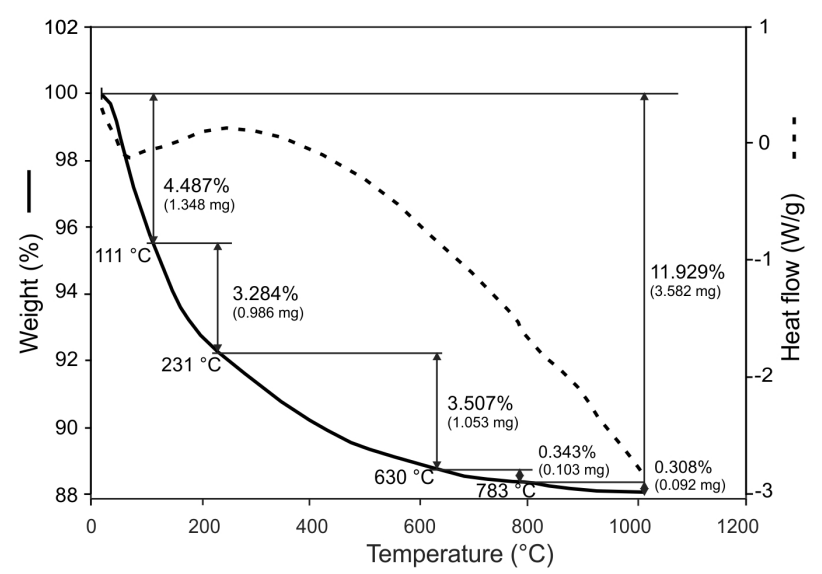

FIgURE 6. DSC (dashed line) and TGA (solid line) curves of the ground ZVB.

due to zeolite-rich addition. The minislump of $\mathrm{OPC}+\mathrm{ZVB}$ remains for $30 \mathrm{~min}$, and thereafter its loss rate is higher than that corresponding to the OPC paste.

\subsubsection{Heat released}

Figure 9 shows the evolution of the heat release rate $(\mathrm{mW} / \mathrm{g})$ and cumulative heat release $(\mathrm{J} / \mathrm{g})$ as a function of time (min) for OPC and OPC+ZVB. 


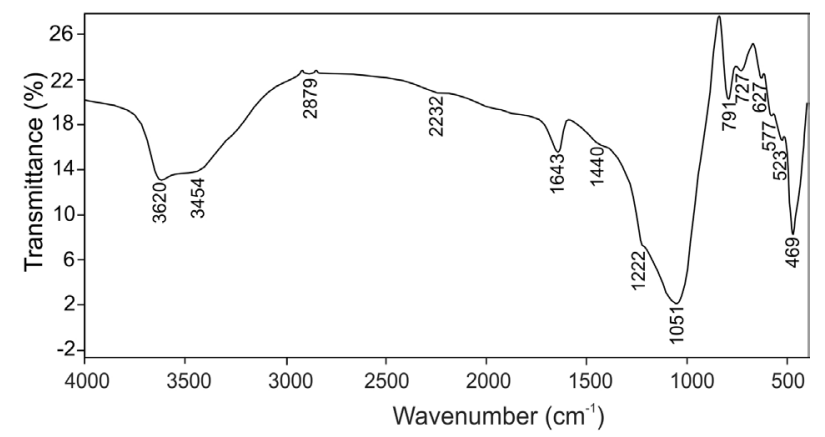

Figure 7. FT-IR curve of the ground ZVB.

TABLE 4. CEC and exchangeable cations of ground ZVB (meq/100g).

\begin{tabular}{lcrrrr}
\hline & & \multicolumn{4}{c}{ Exchangeable cations } \\
\cline { 3 - 6 } Material & CEC & $\mathbf{K}$ & $\mathbf{C a}$ & \multicolumn{1}{c}{ Mg } & Na \\
\hline Ground ZVB & 59.2 & 11.1 & 13.95 & 0.76 & 17.96 \\
\hline
\end{tabular}



Figure 8. Results of minislump test of $\mathrm{OPC}$ and $\mathrm{OPC}+\mathrm{ZVB}$ pastes.

The heat release rate curve is characterized by: a) the initial signal due to dissolution, wetting and initial hydration; b) the dormant period; c) the second peak corresponding to the $\mathrm{C}_{3} \mathrm{~S}$ hydration characterized by the slope, the maximum heat release rate and the occurrence time; d) the third peak associated with $\mathrm{C}_{3} \mathrm{~A}$ hydration due to sulfate depletion characterized by its intensity and the occurrence time.

The initial heat release rate is very high when water is mixed with cementitious materials. Then, the signal decreases to the first valley at $180 \mathrm{~min}$ with a rate of $0.27 \mathrm{~mW} / \mathrm{g}$ for OPC and it occurs $15 \mathrm{~min}$ before with a high rate $(0.40 \mathrm{~mW} / \mathrm{g})$ for

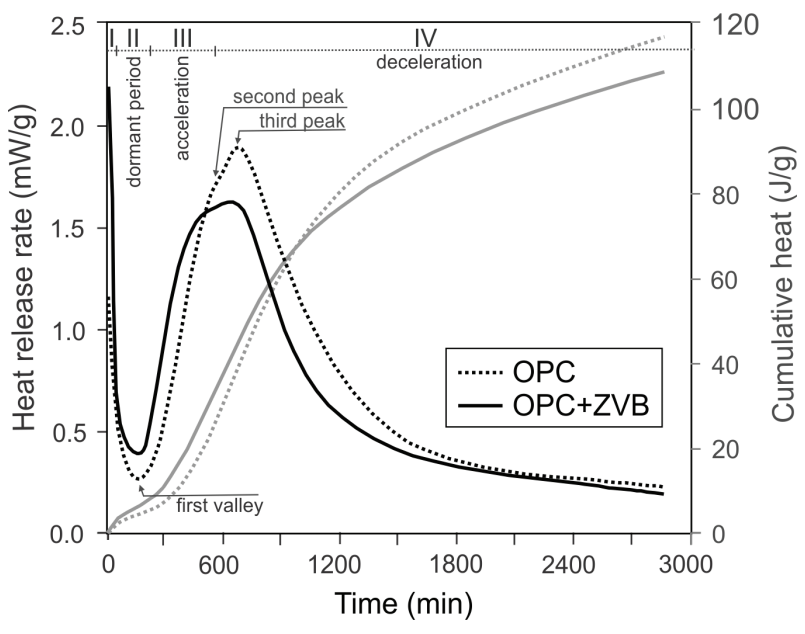

FIGURE 9. Heat release rate and cumulative heat released curves of $\mathrm{OPC}$ and $\mathrm{OPC}+\mathrm{ZVB}$

$\mathrm{OPC}+\mathrm{ZVB}$. For OPC, $\mathrm{C}_{3} \mathrm{~S}$ hydration starts with a sudden heat-rate acceleration $(0.00513 \mathrm{~mW} / \mathrm{g} . \mathrm{min})$ reaching the second peak at $570 \mathrm{~min}$ with a rate of $1.72 \mathrm{~mW} / \mathrm{g}$. For cement with ZVB, it starts with a similar acceleration rate $(0.00516 \mathrm{~mW} / \mathrm{g} . \mathrm{min})$ but the maximum occurs $60 \mathrm{~min}$ before $(510 \mathrm{~min})$ with a low heat rate $(1.57 \mathrm{~mW} / \mathrm{g})$. The sulfate depletion point appears approximately at 610 and $560 \mathrm{~min}$ for $\mathrm{OPC}$ and $\mathrm{OPC}+\mathrm{ZVB}$, respectively. However, it is poorly marked in the curves due to the low $\mathrm{C}_{3} \mathrm{~A}$ content of OPC used. The third peak occurs at 670 min with a rate of $1.87 \mathrm{~mW} / \mathrm{g}$ for OPC and at 630 min with a rate of $1.62 \mathrm{~mW} / \mathrm{g}$ for $\mathrm{OPC}+\mathrm{ZVB}$. The cumulative heat release (Figure 9) shows that the $\mathrm{OPC}+\mathrm{ZVB}$ has a great value up to $\sim 16 \mathrm{~h}$ and then it is lower than that corresponding to OPC.

\subsubsection{Frattini test}

Results of the Frattini test are reported in Figure 10. For OPC, the points representing [CaO] and $\left[\mathrm{OH}^{-}\right]$are above the calcium solubility isotherm, indicating that the solution is saturated in portlandite, except at 90 days when the $[\mathrm{CaO}]$ decrease is attributed to the $\mathrm{CO}_{2}$ dissolved in the supernatant solution. For OPC $+\mathrm{ZVB}$, the points at 2 and 7 days are above the calcium solubility isotherm, revealing no pozzolanic activity. After 28 days, the points fall below the isotherm, indicating that the pozzolanic material reacts with dissolved $\mathrm{Ca}(\mathrm{OH})_{2}$ at a high rate giving an unsaturated supernatant solution. The $[\mathrm{CaO}]$ is higher than that corresponding to OPC at 2 days and it is similar at 7 days, while the $\left[\mathrm{OH}^{-}\right]$ increases slightly. At 28 and 90 days, the $[\mathrm{CaO}]$ is lower than that of $\mathrm{OPC}$, and the $\left[\mathrm{OH}^{-}\right]$increases significantly at later ages. This test determines that $\mathrm{ZVB}$ has good pozzolanic activity and is classified as slow reactive pozzolanic material. 


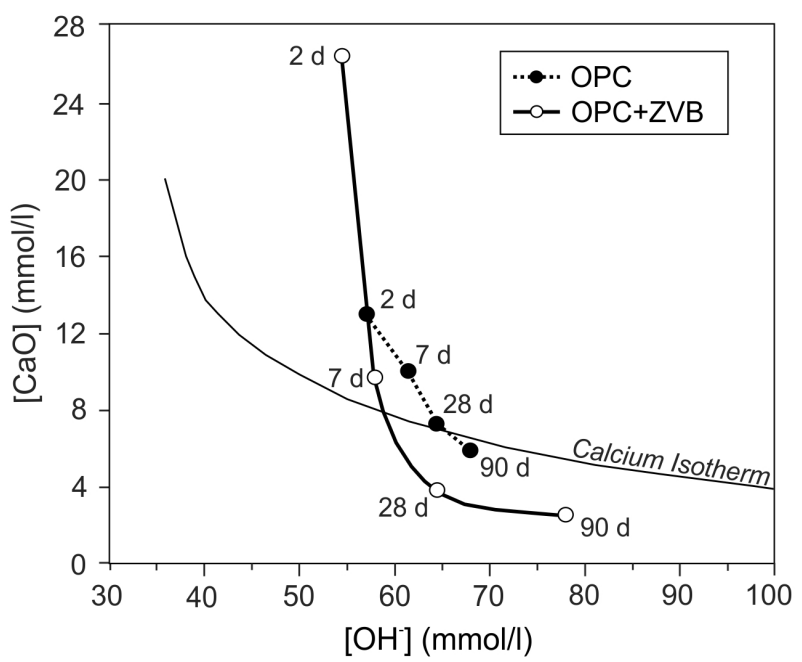

FIGURE 10. Results of the Frattini test of $\mathrm{OPC}$ and $\mathrm{OPC}+\mathrm{ZVB}$.

\subsubsection{Compressive strength and $S A I$}

The mortars used to determine the compressive strength and SAI have a flow of 125\% (OPC) and $91 \%$ (OPC+ZVB). As reported for the minislump, the addition of the zeolitic material reduces the workability of mortar. Figure 11 shows the compressive strength and SAI values for mortars up to 90 days. At early ages ( 2 and 7 days), the compressive strength of OPC+ZVB $(13.3 \mathrm{MPa}$ and $26.3 \mathrm{MPa})$ is lower than that of the OPC mortar (18.6 MPa and $34.8 \mathrm{MPa}$ ). However, the compressive strength at 28 and 90 days (47.3 and $58.2 \mathrm{MPa}$ ) is greater than the compressive strength of OPC (46.6 and 53.7 MPa). The SAI at 28 and 90 days is 1.02 and 1.08 , exceeding the values required by the EN 450-1 standard (34).

\subsubsection{Hydration}

The textural-chemical characteristics of $\mathrm{OPC}+$ ZVB mortar after 90 days of hydration are depicted in Figure 12. The BSE image (Figure 12a) shows the main phases identified according to elemental maps of $\mathrm{Si}, \mathrm{Ca}, \mathrm{Al}, \mathrm{K}, \mathrm{Na}, \mathrm{Fe}, \mathrm{Mg}$ and $\mathrm{S}$ (Figure 12b-i). Sand aggregates (A) are identified by a high Si content (Figure 12b) and the complete absence of $\mathrm{Ca}$, $\mathrm{Al}, \mathrm{K}$ and $\mathrm{Na}$ (Figure 12c-f). The ZVB grains are characterized by high $\mathrm{Si}$ and $\mathrm{Al}$ (Figure 12d), low $\mathrm{Ca}$ (almost zero compared to the cement paste) and abundant content of alkalis ( $\mathrm{Na}$ and $\mathrm{K}$ in Figure $12 \mathrm{e}$ and $12 \mathrm{f}$, respectively). The cement matrix is dominated by high $\mathrm{Ca}$ content and pores appear as black holes in the BSE image. $\mathrm{C}_{4} \mathrm{AF}$ is identified by its light gray color in BSE image (1) and characterized by the superimposition of $\mathrm{Ca}, \mathrm{Al}$ and $\mathrm{Fe}$ (Figure 12e) elemental maps. $\mathrm{C}_{4} \mathrm{AF}$ hydrates are recognized at the grain boundaries (Figure $12 \mathrm{~g}$ ).

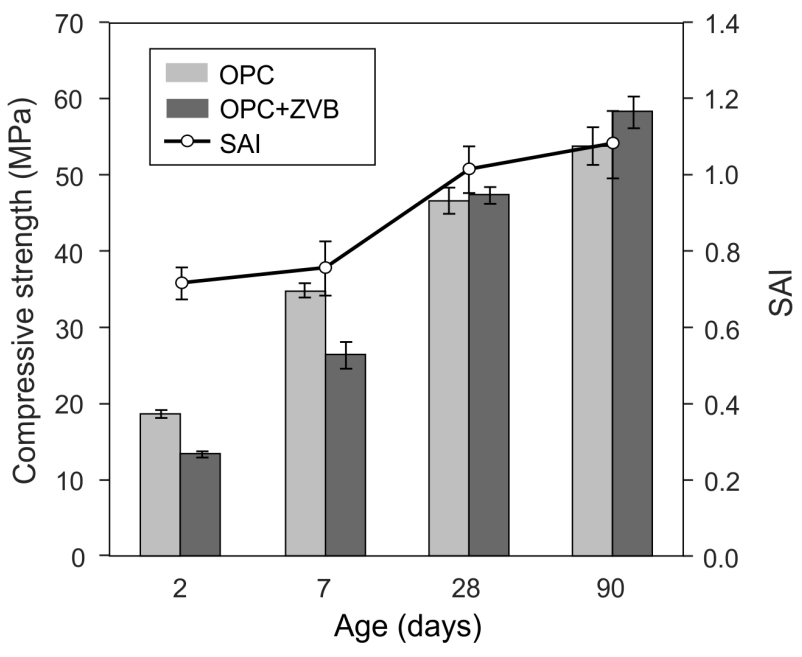

FIGURE 11. Compressive strength and SAI values for OPC and OPC+ZVB mortars.

$\mathrm{CH}$ crystals grow into the pores and also occupy the paste-aggregate interface zone (3). They are characterized by Ca-rich sectors and the absence of other elements. C-S-H, AFm and AFt phases in the paste also grow as intergrowth submicron phases that could not be distinguished using this technique.

Figure 13 (BSE image) shows a detail of the cement paste rich in $\mathrm{ZVB}$ and elemental profiles of $\mathrm{Si}, \mathrm{Ca}, \mathrm{Al}, \mathrm{K}$ and $\mathrm{Na}$ crosscutting the grains. The image shows a rim of Si-rich compound on the surface of the ZVB grains with minor amounts of $\mathrm{Ca}$, $\mathrm{Al}, \mathrm{Na}$ and $\mathrm{K}$. The composition of ZVB grains varies from the center to the boundary, decreasing their concentration in $\mathrm{Si}, \mathrm{Al}, \mathrm{K}$ and $\mathrm{Na}$ (less evident) and increasing the $\mathrm{Ca}$ content. The composition of these compounds at the boundary is related to the C-S-H and C-A-S-H phases, indicating the deposition of pozzolanic reaction products at the ITZ.

Figure 14 shows the evolution of non-evaporable water (Wn) for OPC and OPC+ZVB pastes. In this figure, the dashed line represents the curve corresponding to $75 \% \mathrm{Wn}$ of plain cement. During the test, cement hydration with the zeolitic material produces a smaller Wn amount than the OPC paste. Up to 28 days, the Wn was lower than the proportion equivalent to $75 \%$ of OPC, but it exceeded that value after 28 days. This behavior can be interpreted as a slow contribution to the Wn caused by the pozzolanic reaction.

The XRD patterns for hydrated pastes from 2 to 90 days are presented in Figure 15. For OPC (Figure 15a), at 2 days the $\mathrm{Ca}(\mathrm{OH})_{2}(\mathrm{~d}=4.88 \AA ; 2.63 \AA)$ and ettringite $(\mathrm{d}=9.62 \AA)$ appear as hydration products coexisting with the main anhydrous phases of portland clinker $\left(\mathrm{C}_{3} \mathrm{~S}, \mathrm{C}_{2} \mathrm{~S}\right.$ and $\left.\mathrm{C}_{4} \mathrm{AF}\right)$ as and calcite incorporated as minor constituent. After 7 days, the formation of AFm phase appears (hemicarboaluminate, $\mathrm{d}=8.17 \AA$ ) while ettringite and $\mathrm{Ca}(\mathrm{OH})_{2}$ peaks 


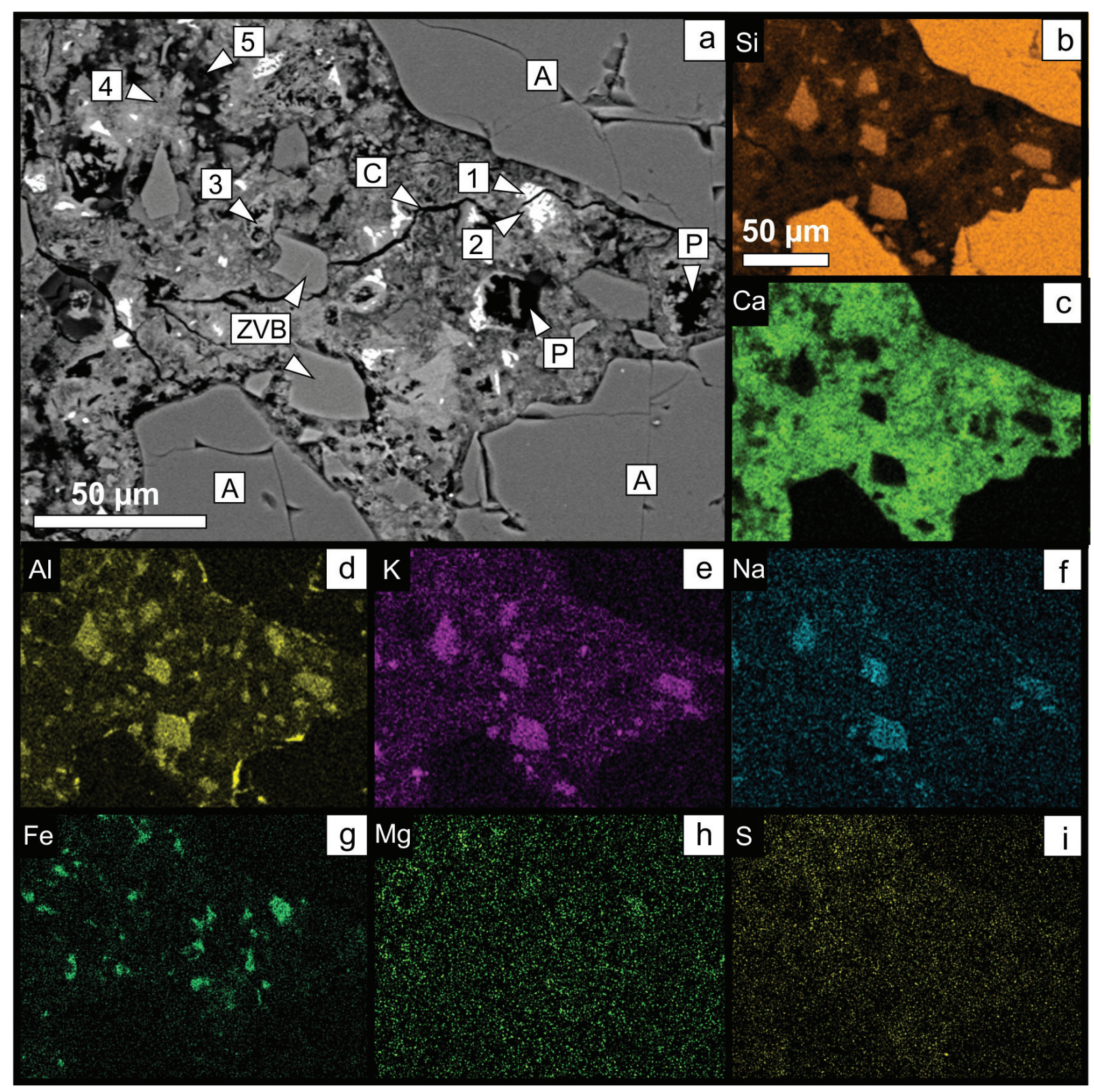

FIGURE 12. SEM-EDS. a) BSE image of OPC+ZVB mortar after 90 days of hydration. b-i) Compositional maps of Si (b), Ca (c), $\mathrm{Al}(\mathrm{d}), \mathrm{K}(\mathrm{e}), \mathrm{Na}(\mathrm{f}), \mathrm{Fe}(\mathrm{g}), \mathrm{Mg}(\mathrm{h})$ and $\mathrm{S}$ (i) of the same sector. (A: siliceous aggregate, C: crack, P: pore, ZVB: zeolitized vitreous breccia, 1: $\mathrm{C}_{4} A F$, 2: hydrated $\mathrm{C}_{4} A F, 3: \mathrm{Ca}(\mathrm{OH})_{2}, 4: \mathrm{Ca}( \pm A l)$-rich $\mathrm{C}-\mathrm{S}$ - $\mathrm{H}$, 5: Si-rich $\left.\mathrm{C}-\mathrm{S}-\mathrm{H}\right)$.

grow. The anhydrous clinker phases decrease. After 28 days, the AFm phase is transformed into monocarboaluminate $(\mathrm{d}=7.55 \AA)$, which is predominant at 90 days together with high intensity $\mathrm{CH}$ peaks. For $\mathrm{OPC}+\mathrm{ZVB}$ paste (Figure 15b), the AFt and AFm phases are absent in the XRD patterns. From 2 to 7 days, the intensity of the $\mathrm{Ca}(\mathrm{OH})_{2}$ peaks increases, it is maintained at 28 days and then it decreases at 90 days, indicating that the pozzolanic reaction progresses. A large proportion of the silicate phases of the cement appear hydrated at 7 days and then fade. The mordenite peaks $(\mathrm{d}=3.97 \AA$, $3.46 \AA$, $3.20 \AA)$ are defined in the XRD patterns at 2 and 7 days, but later they become wider and their intensity decays. However, mordenite peaks are clearly assignable at 90 days.

\section{DISCUSSION}

The ZVB is mainly composed of abundant clasts of perlitic and spherulitic glass of rhyolitic composition, and mordenite zeolite, with crystals of very fine grain size $(<100 \mathrm{~nm})$ and fibrous crystals $(\sim 50 \mu \mathrm{m}$ long), with radial growth predominating. 


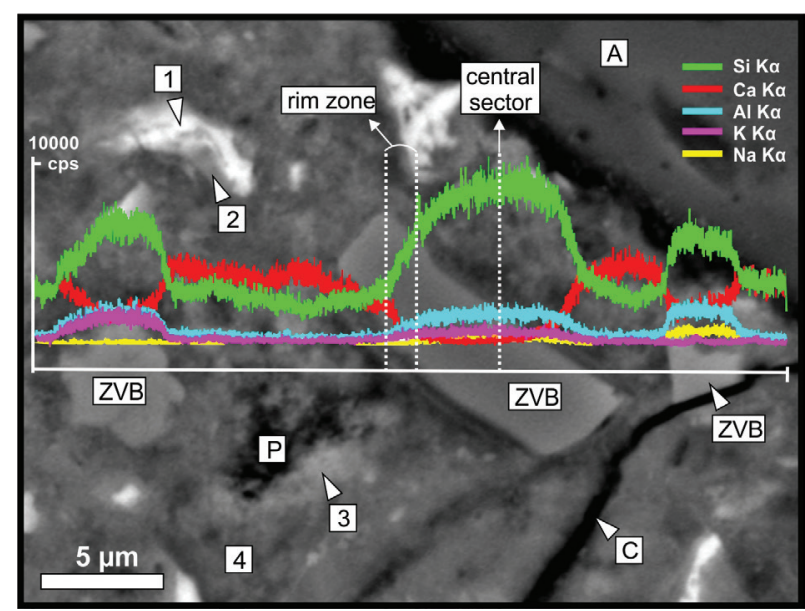

FIGURE 13. SEM-EDS. BSE image of a sector rich in ZVB particles and elemental profiles of $\mathrm{Si}, \mathrm{Ca}, \mathrm{Al}, \mathrm{K}$ and $\mathrm{Na}$. (A: siliceous aggregate, C: crack, P: pore, ZVB: zeolitized vitreous breccia, 1: $C_{4} A F$, 2: hydrated $C_{4} A F$, 3: $\mathrm{Ca}(\mathrm{OH})_{2}$, 4: $\mathrm{Ca}( \pm A l)$-rich $C-S-H)$.

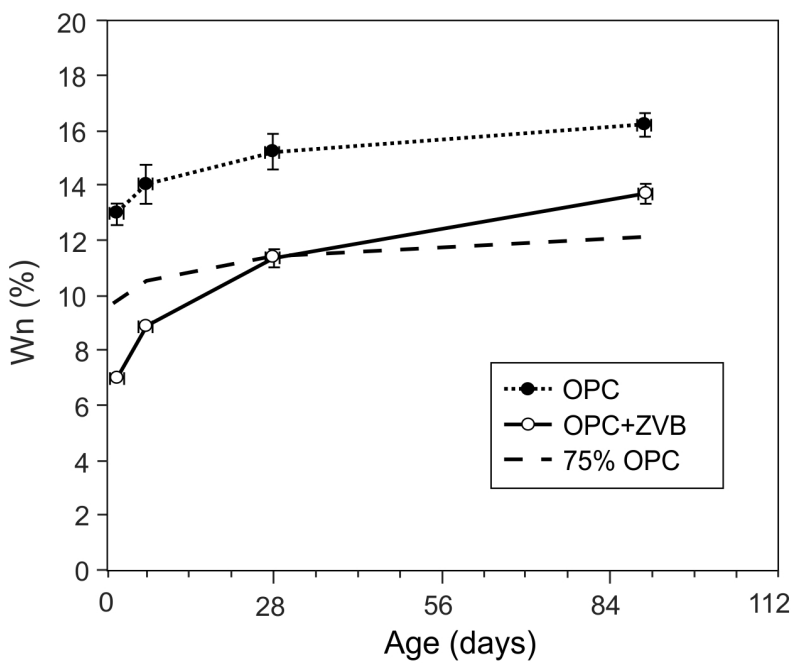

Figure 14. Evolution of the non-evaporable water $(\mathrm{Wn})$ in OPC and OPC+ZVB pastes. Dashed line: $75 \% \mathrm{Wn}$ of plain cement.

The volume and density of the mineralized sectors are variable, forming banks of several meters in thickness, with intercalations of vitreous levels (non-brecciated). The irregularity of the alteration would be linked to the difference in permeability between both sectors.

According to the staining technique implemented, the zeolite content in the studied sample is $\sim 25 \%$, in agreement with the estimation made through CEC determined by $\mathrm{NH}_{4}^{+}$exchange in the ground $\mathrm{ZVB}$. The main cations exchanged were $\mathrm{Na}>\mathrm{Ca}>\mathrm{K}>\mathrm{Mg}$.

FT-IR results indicate the presence of free water in the sample. The mass loss in TGA $(11.9 \%$ - Figure 6$)$ is nearly coincident with water calculated (difference to reach $100 \%$ ) in mordenite by SEM-EDS ( $11.8 \%$ - Table 2$)$, but the mordenite only occupies a quarter of the bulk sample. SEMEDS analysis shows that volcanic glass also has a high water content $(\sim 10.8 \%$ - Table 2$)$. It is higher than in typical non-altered glasses $(\sim 5 \%)$ (49), therefore, it could be partially transformed into zeolite and contributes to the final mass loss measured. However, since both volcanic glass and mordenite contribute to the mass loss during heating, it is difficult to discriminate one from the other in the TGA curve. Although the standard specifies a limit of $10 \%$ for LOI (39), it can be seen that the mass loss between 20 and $110^{\circ} \mathrm{C}$ in the TG curve (Figure 6) due to hygroscopic water is $\sim 4.5 \%$. The mass loss above $\sim 110^{\circ} \mathrm{C}$ is assignable to water held in the zeolite structure and should not be taken into account in the specification indicated by the standard.

The addition of zeolite-bearing pozzolan to portland cement causes several effects: the hydration of the cement occurred much earlier $(12,15,50,51$, $52,53)$, the high exchange capacity of pore solution ions influenced the formation of C-S-H and the later pozzolanic activity. The reactivity depends on the type and characteristics of zeolite, and the mordenite type zeolite appears as slow reactive $(12,17)$.

The large specific surface and porous structure of zeolite can decrease the free water content in the paste, reducing the initial paste minislump or mortar flow and causing the minislump loss (Figure 8). Results of the heat release (Figure 9) and the Frattini test (Figure 10) reveal that the addition of ZVB to OPC stimulates the hydration of the portland cement fraction at early ages. Early stimulation could be attributed to changes in the concentration of ionic species in the pore solution caused by the CEC and the increase of nucleation sites. Furthermore, the replacement by weight of ZVB with lower density than the OPC increases the volume of solids in the paste decreasing the interparticle distance $(54,55)$. The stimulation is controlled by the exchangeable cation (predominantly $\mathrm{Na}$ in this case) with $\mathrm{Ca}$ and $(\mathrm{OH})^{-}(53)$ that reduces the ionic strength in the pore solution, causing a quick dissolution and hydration of portland cement (the calorimetric curve moves to the left) and the second and the third peaks appear at early ages. However, the lower intensity of both peaks reveals the dilution effect caused by the ZVB replacement. In the Frattini test (Figure 10), the stimulation effect increases the $\mathrm{Ca}(\mathrm{HO})_{2}$ released by $\mathrm{C}_{3} \mathrm{~S}$ hydration at early age, and the $[\mathrm{CaO}]$ increases in the supernatant solution. For the $25 \%$ replacement, the stimulation effect cannot compensate the dilution effect, and the compressive strength (Figure 11) and Wn (Figure 14) are much lower than that obtained in the OPC. Low Wn can also be attributed to the absence of AFt and AFm phases in the compound assemblage (Figure 15b) with larger proportion of combined water in their structure. 




FIGURE 15. XRD of hydrated paste at 2, 7, 28 and 90 days; a) OPC, b) OPC+ZVB.

At later ages, the ZVB shows pozzolanic activity, as revealed by the Frattini test. The pozzolanic reaction involves the consumption of $\mathrm{Ca}(\mathrm{OH})_{2}$, and [CaO] decreases in the Frattini diagram up to 90 days. On the other hand, $\left[\mathrm{OH}^{-}\right]$increases indicating that hydroxyl ions are released from rhyolitic glass or zeolite. This pozzolanic reaction contributes to mortar strength, attaining a value similar to that corresponding to OPC. The non-evaporable water increases, but some part of $\mathrm{Ca}(\mathrm{OH})_{2}$ remains in the paste, as revealed by the XRD pattern (Figure 15b) and BSE-SEM analysis (Figure 12).

In the $\mathrm{ZVB}$, aluminum is mainly present in glass and mordenite $\left(\sim 11 \%-12 \% \mathrm{Al}_{2} \mathrm{O}_{3}\right)$. In recent experiences (56) it was observed that ZVB is transformed almost completely into Na-P zeolite when it is maintained in a $1 \mathrm{~N} \mathrm{NaOH}$ solution for 6 weeks $\left(\right.$ at $40^{\circ} \mathrm{C}$ ) or in a mixture of Na-P zeolite and analcime for 4 weeks (at $95^{\circ} \mathrm{C}$ ). According to Blanc et al. (57), mordenite is not stable in the high $\mathrm{pH}$ conditions of the concrete. In this scenario and assuming a system saturated with respect to calcium, it is expected that Al-rich zeolites or Al-containing cement phases will stabilize. In the case of ZVB, $70 \%-75 \%$ of the material corresponds to rhyolitic volcanic glass, of known instability in alkaline conditions (55). Therefore, it is possible that pozzolan (mainly glass particles and possibly mordenite) react to form more stable C-S-H and/or Al-containing phases, mainly at the periphery of the particles (Figure 13).

However, mordenite peaks in the XRD pattern (Figure 15b) remain at 90 days, indicating that the pozzolanic activity could mainly be attributed to the glass phases included in the ZVB. This behavior was also corroborated by SEM-EDS results (Figure 12). It is observed that the pozzolan grains remain in the bulk mass of mortar with a high content of Si, Al and $\mathrm{K}$, and the pozzolanic reaction products form a rim around the grain, possibly due to the vitreous content in the breccia (Figure 13). In addition, alkalis could also be released by dissolution of rhyolitic glass, increasing $\left[\mathrm{OH}^{-}\right]$in the Frattini test at 90 days. Transformation of mordenite into more stable phases is not discarded, due to its chemical 
instability in high alkaline solutions, but more studies are needed in order to completely understand its role in volcanic pozzolan performance.

Summarizing, the addition of ZVB to cement causes two main effects. At early ages, the water demand increases due to the high specific surface and the high CEC of ZVB, reducing the minislump and the mortar flow. On the other hand, the cement hydration reactions are stimulated, but the high hydration degree of OPC fraction cannot compensate the dilution effect caused by $25 \%$ of replacement. Later, the pozzolanic reaction increases the combined water and the relative compressive strength (SAI > 1.00) of the blended cement. The pozzolanic reaction is mainly attributed to the glass reaction, and to a lesser extent to the mordenite-type zeolite. XRD and SEM-EDS studies reveal that mordenite and $\mathrm{Ca}(\mathrm{OH})_{2}$ remains in the paste and mortar after 90 days.

\section{CONCLUSIONS}

This vitreous breccia contains some sectors rich in volcanic glass and others partially to completely altered to mordenite. This irregular mineralization of the rock requires a comprehensive evaluation of the material to estimate its potential use as a pozzolan. Textural and mineralogical characterization by optical microscopy, XRD and SEM-EDS is highly recommended. The proportion of mordenite and glass in the bulk sample estimated with the methylene blue staining technique and imaging processing is $\sim 25 \%$, comparable with the estimation made through CEC determined on the homogenized ground ZVB.

Textural and mineralogical analyses show that ZVB is heterogeneous, with vitreous areas slightly zeolitized and other sectors strongly altered to zeolite. The most distributed phase replacing the vitreous material is fine-grained mordenite with no obvious habit, while the fibrous variety of this mineral and prismatic clinoptilolite are less abundant. K-feldspar, plagioclase, opal-CT, Ti- or Fe-oxides/ hydroxides and clay minerals were identified as accessory phases $(<1 \%)$.

The ZVB does not meet the LOI limit of ASTM C618 standard. Results of DSC-TGA and FT-IR complemented by bulk (ICP) and chemical analyses (SEM-EDS) of each phase confirm that zeolite and glass have similar chemical composition with $\sim 11.5 \%$ of water. However, only $\sim 4.5 \%$ is lost up to $\sim 110{ }^{\circ} \mathrm{C}$, assignable to hygroscopic water, and the rest (above $110^{\circ} \mathrm{C}$ ) is assignable to water held in the zeolite structure.

Two main effects were observed when ZVB was used as SCM. First, the water demand increases at early ages, reducing the minislump and the mortar flow. Second, the pozzolanic reaction increases the combined water and the relative compressive strength (SAI > 1.00) of the blended cement.
The pozzolanic reaction can mainly be attributed to the high reactivity of volcanic glass in alkaline conditions, while the zeolitization of volcanic glass contributes to increasing the exposed surface and ion transport for the pozzolanic reaction.

\section{ACKNOWLEDGEMENTS}

Financial support was provided by PICT 2015 $\mathrm{N}^{\mathrm{o}} 367$ (FONCyT). Authors thank (UN del Centro de la Provincia de Buenos Aires, Comisión de Investigaciones Científicas de la Provincia de Buenos Aires- CONICET); CICTERRA (CONICET-UN Córdoba); Departamento de Geología - UNl del Sur and Centro de Geología Aplicada, Agua y Medio Ambiente (CGAMA-CIC-UNS).

\section{REFERENCES}

1. Scrivener, K.L.; John, V.M.; Gartner, E.M. (2017) Ecoefficient cements: Potential economically viable solutions for low-CO $\mathrm{O}_{2}$ cement-based materials industry, Revised Edition, United Nations Environment Programme, Paris, France.

2. Damtoft, J.S.; Lukasik, J.; Herfort, D.; Sorrentino, D.; Gartner, E.M. (2008) Sustainable development and climate change initiatives. Cem. Concr. Res. 38[2], 115-127. https:// doi.org/10.1016/j.cemconres.2007.09.008

3. Valipour, M.; Yekkalar, M.; Shekarchi, M.; Panahi, S. (2014) Environmental assessment of green concrete containing natural zeolite on the global warming index in marine environments. J. Clean Prod. 65, 418-423. https:// doi.org/10.1016/j.jclepro.2013.07.055

4. ACI Committee 232 (2012) Report on the use of raw or processed natural pozzolans in concrete, ACI $232.1 \mathrm{R}$, American Concrete Institute, Farmington Hills, USA.

5. Massazza, F. (1998) Pozzolana and pozzolanic cements, In: Hewlett, P.C. (Ed.), Lea's Chemistry of Cement and Concrete, Elsevier, Amsterdam, pp. 471-635.

6. Passaglia, E.; Sheppard, R.A. (2001) The crystal chemistry of zeolites. In: Bish, D.L.; Ming, D.W. (Eds.), Natural zeolites: occurrences, properties, applications. Reviews in Mineralogy and Geochemistry 45, Mineralogical Society of America, Chantilly, USA, pp. 69-116. https://doi. org/10.1515/9781501509117-004

7. Coombs, D.S.; Alberti, A.; Armbruster, T.; Artioli, G.; Colella, C.; Galli, E.; Grice, J.D.; Liebau, F.; Mandarino, J.A.; Minato, H.; Nickel, E.H.; Passaglia, E.; Peacor, D.R.; Quartieri, S.; Rinaldi, R.; Ross, M.; Sheppard, R.A.; Tillmanns, E.; Vezzalini, G. (1998) Recommended nomenclature for zeolite minerals: report of the subcommittee on zeolites of the International Mineralogical Association, Commission on New Minerals and Mineral Names, Miner. Mag. 62[4], 533-571. https://doi.org/ $10.1180 / 002646198547800$

8. Bish, D.L.; Carey, J.W. (2001) Thermal behavior of natural zeolites. In: Bish, D.L.; Ming, D.W. (Eds.), Natural zeolites: occurrences, properties, applications. Reviews in Mineralogy and Geochemistry 45, Mineralogical Society of America, Chantilly, USA, pp. 403-452. https://doi. org/10.1515/9781501509117-015

9. Auerbach, S.M.; Carrado, K.A.; Dutta, P.K. (2003) Handbook of zeolite science and technology, Marcel Dekker, Inc., New York, 2003.

10. Colella, A.; Di Benedetto, C.; Calcaterra, D.; Cappelletti, P.; D’Amore, M.; Di Martire, D.; Graziano, S.F.; Papa, L.; de Gennaro, M.; Langella, A. (2017) The Neapolitan Yellow Tuff: An outstanding example of heterogeneity. Constr: Build. Mater. 136[1], 361-373. https://doi.org/10.1016/j. conbuildmat.2017.01.053 
11. Fragoulis, D.; Chaniotakis, E.; Stamatakis, M.G. (1997) Zeolitic tuffs of Kimolos Island, Aegean Sea, Greece and their industrial potential. Cement Concrete Res. 27[6], 889-905. https://doi.org/10.1016/S0008-8846(97) $00072-0$

12. Mertens, G.; Snellings, R.; Van Balen, K.; Bicer-Simsir, B.; Verlooy, P.; Elsen, J. (2009) Pozzolanic reactions of common natural zeolites with lime and parameters affecting their reactivity. Cem. Concr. Res. 39[3], 233-240. https:// doi.org/10.1016/j.cemconres.2008.11.008

13. Vigil de la Villa, R.; Fernández, R.; García, R.; Villar-Cociña, E.; Frías, M. (2009) Pozzolanic activity and alkaline reactivity of a mordenite-rich tuff. Micropor. Mesopor. Mat. 126[1-2], 125-132. https://doi.org/10.1016/j.micromeso.2009.05.029

14. Janotka, I.; Mojumdar; S.C. (2003) Hydration of portland cement, natural zeolite mortar in water and sulphate solution. Mater. Construcc. 53[269], 17-27. https://doi. org/10.3989/mc.2003.v53.i269.265.

15. Snellings, R.; Mertens, G.; Cizer, Ö.; Elsen, J. (2010) Early age hydration and pozzolanic reaction in natural zeolite blended cements: Reaction kinetics and products by in situ synchrotron X-ray powder diffraction. Cem. Concr. Res. 40[12], 1704-1713. https://doi.org/10.1016/j.cemconres. 2010.08 .012

16. Cornejo, M.H.; Elsen, J.; Paredes, C.; Baykara, H. (2015) Hydration and strength evolution of air-cured zeolite-rich tuffs and siltstone blended cement pastes at low waterto-binder ratio. Clay Min. 50[1], 133-152. https://doi.org/ 10.1180/claymin.2015.050.1.12

17. Özen, S.; Göncüoğlu, M.C.; Liguori, B.; de Gennaro, B.; Cappelletti, P.; Gatta, G.D.; Iucolano, F.; Colella, C. (2016) A comprehensive evaluation of sedimentary zeolites from Turkey as pozzolanic addition of cement- and lime-based binders. Constr. Build. Mater. 105, 46-61. https://doi. org/10.1016/j.conbuildmat.2015.12.055

18. Chen, J.J.; Li, L.G.; Ng, P.L.; Kwan, A.K.H. (2017) Effects of superfine zeolite on strength, flowability and cohesiveness of cementitious paste. Cem. Concr. Comp. 83, 101-110. https://doi.org/10.1016/j.cemconcomp.2017.06.010

19. Snellings, R: Mertens, G; Gasharova, B ; Garbev, K. Elsen, J. (2010) The pozzolanic reaction between clinoptilolite and portlandite: a time and spatially resolved IR study. Eur. J. Mineral. 22[6], 767-777. https://doi.org/ 10.1127/0935-1221/2010/0022-2019

20. Poon, C.S.; Lam, L.; Kou, S.C.; Lin, Z.S. (1999) A study on the hydration rate of natural zeolite blended cement pastes. Constr. Build. Mater. 13[8], 427-432. https://doi. org/10.1016/S0950-0618(99)00048-3

21. Najimi, M.; Sobhani, J.; Ahmadi, B.; Shekarchi, M. (2012) An experimental study on durability properties of concrete containing zeolite as a highly reactive natural pozzolan. Constr. Build. Mater. 35, 1023-1033. https://doi. org/10.1016/j.conbuildmat.2012.04.038

22. Gargiulo, M.; Crosta, S.; Leal, P.; Vattuone, M. (2017) Las zeolitas naturales de Argentina. In: Costafedra Mustelier, J.L.; Sánchez, D.A.M.; Costafedra Velázquez, J.L. (Eds.), Las zeolitas naturales de Iberoamérica, Fundación Gómez Pardo, Madrid, 58-136.

23. Raggiotti, B.B.; Positieri, M.J.; Locati, F.; Murra, J.; Marfil, S. (2015) Zeolite, study of aptitude as a natural pozzolan applied to structural concrete, Rev. Construcc. 14[2], 14-20. https://doi.org/10.4067/S0718-915X2015000200002

24. Locati, F.; Falcone, D.; Marfil, S.; Raggiotti, B. (2015) Use of natural zeolites as ASR inhibitor in basaltic rocks. In: Villagrán-Zaccardi, Y.; Zega, C.; Torrijos, M.C. (Eds.), International Conference on Sustainable Structural Concrete (Sustain Concrete 2015), RILEM-LEMIT, La Plata, Argentina,. 381-392.

25. Rasband, W.S. (2018) ImageJ, U.S. National Institute of Health, Bethesda, Maryland, USA, https://imagej.nih.gov/ij/

26. ASTM C430 (2017) Standard test method for fineness of hydraulic cement by the $45-\mu \mathrm{m}$ (No. 325) sieve, ASTM International, West Conshohocken, PA, USA.

27. ASTM C188 (2017) Standard test method for density of hydraulic cement, ASTM International, West Conshohocken, PA, USA
28. ASTM C204 (2018), Standard test methods for fineness of hydraulic Cement by air-permeability apparatus, ASTM International, West Conshohocken, PA, USA.

29. EPA (2007) Method 3051A.U.S. EPA Method 3051A (SW-846): Microwave Assisted Acid Digestion of Sediments, Sludges, and Oils, Revision 1, United States Environmental Protection Agency, Washington, DC, USA.

30. EPA (1994) Method 200.7, Method 200.7: Determination of Metals and Trace Elements in Water and Wastes by Inductively Coupled Plasma-Atomic Emission Spectrometry, Revision 4.4, United States Environmental Protection Agency, Cincinnati, OH, USA.

31. IRAM 1654 (2015) Puzolanas y Cenizas volantes silíceas. Parte 1: Métodos de ensayos físicos (Pozzolans and siliceous fly ash. Part 1: Physical test methods), IRAM, Buenos Aires, Argentina.

32. Kantro, D. (1980) Influence of water-reducing admixtures on properties of cement paste - a miniature slump test. Cem. Concr. Aggr. 2[2], 95-102. https://doi.org/10.1520/ CCA10190J

33. EN 196-5 (2011) Methods of testing cement. Part 5: Pozzolanicity test for pozzolanic cement, British Standard Institution, London, UK.

34. EN 450-1 (2012) Fly ash for concrete. Part 1: Definition, specification and conformity criteria, British Standard Institution, London, UK.

35. EN 196-1 (2016) Methods of testing cement. Part 1: Determination of strength, British Standard Institution, London, UK.

36. ASTM C1437 (2015) Standard Test Method for Flow of Hydraulic Cement Mortar, ASTM International, West Conshohocken, PA, USA.

37. Powers, TC. (1949) The non-evaporable water content of hardened portland-cement paste. Its significance for concrete research and its method of determination, ASTM Bulletin.158, 68-76.

38. Bengochea, L.; Mas, G.; Maiza, P.; Bengochea, J. (1997) Mordenite occurrence in the Mendoza Province, Argentina. In: Zeolite '97. 5th International Conference on the occurrence, properties and utilization of natural zeolites, Ischia, Italy, 63-64

39. ASTM C 618 (2017) Standard specification for coal fly ash and raw or calcined natural pozzolan for use in concrete, ASTM International, West Conshohocken, PA, USA

40. Van Reeuwijk, L.P. (1974) The thermal dehydration of natural zeolites. Mededelingen Landbouwhogeschool Wageningen, 74-79. H. Veenman \& Zonen B.V., Wageningen, Netherlands.

41. Adriano, A.; Soriano, G.; Duque, J. (2013) Characterization of water absorption and desorption properties of natural zeolites in Ecuador. In: Fifth International Symposium on Energy, Puerto Rico Energy Center-Laccei, Puerto Rico, $1-9$.

42. Zvereva, I.; Kremnev, R.; Sirotov, V.; Rodríguez-Iznaga, I.; Hernández, M.A.; Petranovskii, V. (2017) Thermal analysis and porosimetry of natural zeolites from Mexican and Cuban deposits. App. Solid State Chem. 1, 35-41. https:// doi.org/10.18572/2619-0141-2017-1-1-35-41

43. Pechar, F. Rykl, D. (1987) Thermal decomposition of natural mordenite, Chem. Pap. 41[3], 351-362. https://www. chempap.org/?id=7\&paper $=4287$

44. Földvári, M. (2011) Handbook of thermogravimetric system of minerals and its use in geological practice. Occasional Papers of the Geological Institute of Hungary 213, Geological Institute of Hungary, Budapest, Hungary.

45. Jansen, J.C.; van der Gaag, F.J.; van Bekkum, H. (1984) Identification of ZSM-type and other 5-ring containing zeolites by IR spectroscopy. Zeolites, 4[4], 369-372. https:// doi.org/10.1016/0144-2449(84)90013-7

46. Deshpande, V.P.; Bhoskar, B.T. (2012) Ion exchange and dielectric study of mordenite, International Journal of Engineering Research \& Technology, 1[8], 1-22.

47. Ostroumov, M.; Corona-Chávez, P.(2003) Mineralogical study of mordenite from the Sierra Madre del Sur, southwestern Mexico. Rev. Mex. Cienc. Geol. 20[2], 133-138.

48. Mumpton, F.A. (1999) La roca mágica: Uses of natural zeolites in agriculture and industry. Proceedings of the National 
Academy of Sciences of the Unites States of America. 96[7], 3463-3470. https://doi.org/10.1073/pnas.96.7.3463

49. Tazaki, K.; Tiba, T.; Aratani, M.; Miyachi, M. (1992) Structural water in volcanic glass, Clay Clay Min. $40[1], \quad 122-127$. https://doi.org/10.1346/CCMN.1992. 0400113

50. Martínez-Ramírez, S.; Blanco-Varela, M.T.; Ereña, I.; Gener, M. (2006) Pozzolanic reactivity of zeolitic rocks from two different Cuban deposits: Characterization of reaction products. Appl. Clay Sci. 32[1-2], 40-52. https:// doi.org/10.1016/j.clay.2005.12.001

51. Caputo, D.; Liguori, B.; Colella, C. (2008) Some advances in understanding the pozzolanic activity of zeolites: The effect of zeolite structure. Cem. Concr. Comp. 30[5], 455-462. https://doi.org/10.1016/j.cemconcomp.2007.08.004

52. Tydlitát, V.; Zákoutský, J.; Černý, R. (2014) Early-stage hydration heat development in blended cements containing natural zeolite studied by isothermal calorimetry. Thermochimica Acta. 582, 53-58. https://doi.org/10.1016/j. tca.2014.03.003

53. Rahhal, V.F.; Pavlík, Z.; Tironi, A.; Castellano, C.C.; Trezza, M.A.; Černý, R.; Irassar, E.F. (2017) Effect of cement composition on the early hydration of blended cements with natural zeolite. J Therm Anal Calorim. 128[2], 721-733. https://doi.org/10.1007/s10973-016-6007-4

54. Bentz, D.P.; Ferraris, C.F.; Galler, M.A.; Hansen, A.S.; Guynn, J.M. (2012) Influence of particle size distributions on yield stress and viscosity of cement-fly ash pastes. Cem. Concr. Res. 42[2], 404-409. https://doi.org/10.1016/j. cemconres.2011.11.006

55. Guo, Y.; Zhang, T.; Wei, J.; Yu, Q.; Ouyang, S. (2017) Evaluating the distance between particles in fresh cement paste based on the yield stress and particle size. Constr. Build. Mater. 142, 109-116. https://doi.org/10.1016/j. conbuildmat.2017.03.055

56. Locati, F.; Marfil, S.; Lescano, L.; Madsen, L.; Cravero, F.; Castillo, L.; Barbosa, S.; Maiza. P. (2017) Síntesis de zeolita Na-P en solución alcalina a partir de una toba vítrea parcialmente zeolitizada. Revista de Geología Aplicada a la Ingeniería y al Ambiente, 39, 1-7. https://www.editoresasagai.org.ar/ojs/index.php/rgaia/article/view/140

57. Blanc, P.; Vieillard, P.; Gailhanou, H.; Gaboreau, S.; Marty, N.; Claret, F.; Madé, B.; Giffaut, E. (2015) ThermoChimie database developments in the framework of cement/ clay interactions. Appl. Geochem. 55, 95-107. https://doi. org/10.1016/j.apgeochem.2014.12.006 